\title{
Considering the academy: academics, public intellectuals and activism
}

\section{Emma Weitkamp}

Abstract

Keywords
Reflecting on the public role of academics, this issue of JCOM includes a set of commentaries exploring public intellectuals and intellectualism. The commentaries explore the role of academics in public debates, both as bringers of facts and passion. These pieces, together with past commentaries and letters to JCOM raise interesting questions about the role of academics in public debates that are, perhaps not those usually trodden in the academic literature.

Scholarly communication

I recently sat on the judging panel for the 'Celebrating Impact' prizes awarded by the Economic and Social Research Council (U.K.). ${ }^{1}$ Impact categories awarded through this prize reflect the wide-ranging impacts that social science has on society, including business engagement, policy impact and societal impact. These are, of course, all areas addressed through public engagement and knowledge exchange activities and reflect social and funder agendas that are encouraging academics from stepping out of the academy and engaging in public discourse. A topic brought up in the commentaries published in this issue of JCOM, which considers the ways in which scientists become public intellectuals. Rod Lamberts [2017] starts the discussion by exploring what a public intellectual is, arriving at the conclusion that to be a public intellectual requires the intention to enter into debates with the purpose of seeking change. As he states: 'Here the science communication academic becomes more than convertor of jargon into day-to-day language. Now they are agents of social change, of political engagement. In short, now they visibly represent a standpoint' [p. 3].

This set of commentaries offers a variety of views from practicing scientists [Johnson, 2017], science communicators [Olson, 2017; Walker, 2017] and academics in other disciplines [Stokes, 2017]. It explores the value of engaging in social debate as well as the challenges and rewards of so doing. The commentaries are complemented by a letter arguing for greater engagement in social activism from the academic community. Roche and Davis [2017] ask the question 'should science communication play a role in political activism?' arguing that the trend in scepticism towards science means it's vital that academics engage in public debate. They note that the onus for this lies with more senior academics given that many

\footnotetext{
${ }^{1}$ http:/ / www.esrc.ac.uk/research/celebrating-impact-prize/.
} 
early career scientists are on short term, insecure contracts that make standing up (or out) more challenging.

Political activism does come with challenges; academics that take sides are no longer neutral and likely won't be seen as neutral sources by the media. In politicised debates can be ugly, with both sides misusing and abusing information. An academic that comes down strongly on one side of the debate will not be trusted by those on the other. We know from public opinion research that facts alone are not sufficient to change opinions [see for example, Ellerton, 2014; Hart and Nisbet, 2012; Nisbet, 2005]; politicians are perfectly able to ignore scientific advice, even when the weight of such evidence is strongly on one side of the argument. So entering the political fray or seeking to influence the public discourse needs careful consideration.

This is not the first time that JCOM has addressed the question of advocacy. Bandelli [2015], Conde [2015], Isopp [2015], Ottinger [2015] and Testart [2015] and Trautmann [2015] consider the role of scientists as activists. By and large, each believes there are times and places when such advocacy is necessary, but recognise the credibility tension. As Bandelli [2015] states: 'Activism adds a layer of social purpose to the endeavour of research, and might compromise its objectivity. An activist purpose might therefore distort or even "corrupt" the enterprise of science.' [p. 1] Bandelli argues that it is essential that we unpick and understand the drivers behind research 'a healthy, self-critical and reflexive professional field.' [p. 1] This doesn't have to mean taking an activist position, though several contributors to this set of commentaries feel that this is sometimes necessary. But it does mean 'reflecting on the values that drive the scientific endeavour and how they interface, overlap, reinforce or conflict with social and political ones.' [Bandelli, 2015, p. 1]

So, what roles should academics play in the public arena. Should we stand back, offering information (fact?) for use (or misuse) in the public realm? This approach allows us to engage with both groups involved in debate; which can be hugely valuable in reaching out. Skilfully done, such academics can contribute to a more balanced discussion, avoiding the problem of being seen as 'in the pockets' of one side or the other. Yet, there are times when the weight of evidence (or indeed an individual's own passion) is such that a more active role in pushing for a particular understanding or set of outcomes is the only reasonable course of action. While in the heat of debate it may not always be easy to spot the best course of action, but as we see from the reflections in this issue, it is worth taking time to consider ones route and position.

Bandelli, A. (2015). 'The blurred boundaries between science and activism'. JCOM 14 (02), C01.

URL: https://jcom.sissa.it/archive/14/02/JCOM_1402_2015_C01.

Conde, M. (2015). 'From activism to science and from science to activism in environmental-health justice conflicts'. JCOM 14 (02), C04. URL: https : / j jcom .sissa.it/archive/14/02/JCOM_1402_2015_C01/JCOM_1402_2015_C04.

Ellerton, P. (2014). Why facts alone don't change minds in our big public debates. URL: http://theconversation. com/why-facts-alone-dont-change-minds-in - our-big-public-debates-25094 (visited on 11th March 2017). 
Hart, P. S. and Nisbet, E. C. (2012). 'Boomerang Effects in Science Communication: How Motivated Reasoning and Identity Cues Amplify Opinion Polarization About Climate Mitigation Policies'. Communication Research 39, pp. 701-723.

Isopp, B. (2015). 'Scientists who become activists: are they crossing a line?' JCOM 14 (02), C03. URL: https://jcom.sissa.it/archive/14/02/JCOM_1402_2015_C01 /JCOM_1402_2015_C03.

Johnson, E. L. (2017). 'Why Speak?' JCOM 16 (01), C02. URL: https://jcom. sissa .it/archive/16/01/JCOM_1601_2017_C01/JCOM_1601_2017_C02.

Lamberts, R. (2017). 'Science communication: frequently public, occasionally intellectual'. JCOM 16 (01), p. C01.

URL: https://jcom.sissa.it/archive/16/01/JC0M_1601_2017_C01.

Nisbet, M. C. (2005). 'The Competition for Worldviews: Values, Information, and Public Support for Stem Cell Research'. International Journal of Public Opinion Research 17 (1), pp. 90-112. DOI: 10.1093/ijpor/edh058.

Olson, R. (2017). 'Evolution of a public intellectual: coral reef biologist Jeremy Jackson'. JCOM 16 (01), p. C04. URL: https://jcom.sissa.it/archive/16/01/J COM_1601_2017_C01/JCOM_1601_2017_C04.

Ottinger, G. (2015). 'Is it good science? Activism, values, and communicating politically relevant science'. JCOM 14 (02), C02. URL: https://jcom.sissa.it/a rchive/14/02/JCOM_1402_2015_C01/JCOM_1402_2015_C02.

Roche, J. and Davis, N. (2017). 'Should science communication play a role in political activism?' JCOM 16 (01), L01. URL: https://jcom.sissa.it/archive/16/01/JCOM_1601_2017_L01.

Stokes, P. (2017). 'Science communication and the public intellectual: a view from philosophy'. JCOM 16 (01), C03. URL: https://jcom. sissa.it/archive/16/01 /JCOM_1601_2017_C01/JCOM_1601_2017_C03.

Testart, J. (2015). 'Is a science critic a thug?' JCOM 14 (02), C06. URL: https: // jcom .sissa.it/archive/14/02/JCOM_1402_2015_C01/JCOM_1402_2015_C06.

Trautmann, A. (2015). 'On activism of European researchers about science policy'. JCOM 14 (02), p. C05. URL: https://jcom.sissa.it/archive/14/02/JCOM_1402 _2015_C01/JCOM_1402_2015_C05.

Walker, K. (2017). 'Babelfish and the peculiar symbiosis of public intellectualism and academia'. JCOM 16 (01), C05. URL: https://jcom. sissa.it/archive/16 /01/JCOM_1601_2017_C01/JCOM_1601_2017_C05.

Author

Dr. Emma Weitkamp is an Associate Professor in Science Communication and Co-Director of the Science Communication Unit at the University of the West of England, Bristol where she teaches on an MSc in Science Communication and provides training in science communication for practitioners and Ph.D. students. Emma is also Editor in Chief of JCOM. E-mail: Emma.Weitkamp@uwe.ac.uk.

\section{How to cite}

Weitkamp, E. (2017). 'Considering the academy: academics, public intellectuals and activism'. JCOM 16 (01), E. 